\title{
Industry 4.0 and explosion prevention
}

\author{
Marek Woliński ${ }^{1, *}$ \\ ${ }^{1}$ The Main School of Fire Service, Faculty of Fire Safety Engineering, 52/54 Slowackiego St., 01-629 \\ Warsaw, Poland
}

\begin{abstract}
Industry 4.0 creates so called "smart factory", what involves cyber - physical systems, the Internet of things, cloud computing and cognitive computing. One of design principles in Industry 4.0 is technical assistance, understood as the ability of cyber - physical systems to support humans physically by conducting a range of tasks that are unpleasant, too exhausting or unsafe for their human co - workers. Such new approach to production will affect, among others, area of workplace safety and machine safety - also, at the field of explosion safety for works performed in areas with potentially explosive atmospheres. At present, this important issue is regulated in EU by Directive 1999/92/EC (ATEX Worker Directive), Directive 2014/34/EU (ATEX Directive), harmonized national law and technical standards. However, one of important challenges in implementation of idea of Industry 4.0 is lack of regulations, standards and forms of certification. Presented paper discusses problem if existing regulations concerning explosion safety are adequate for such new conditions, sometimes referred to as the fourth industrial revolution.
\end{abstract}

\section{Introduction}

Industry 4.0 - the most current trend of automation and data exchange in manufacturing technologies - originates from the German government high-tech strategy project promoting the computerization of manufacturing [1]. Among four design principles in Industry 4.0 one can find technical assistance, which is understood as the ability of cyberphysical systems to physically support humans by conducting a range of tasks that are unpleasant, too exhausting, or unsafe for their human co-workers [2]. Such idea could be implemented as unmanned assembly line (Fig. 1 below) or as robots co-operating with human personnel at certain workplaces (Fig. 2 below). Expected effect of Industry 4.0 in global economy will be the strong customization of products under the conditions of highly flexible mass-production. However, possible benefits are related with important socioeconomical challenges, as e.g. insufficient qualifications of employees, loss of many jobs to automatic processes and IT-controlled processes, especially for lower educated parts of society [3] (so, probably relations between human workers and collaborative robot will not be so friendly as illustrated in Fig. 2B). Also, the possible benefits are related to strong impact of Industry 4.0 on such area (among others) as machine safety and workplace safety, and the question is if the existing regulations, standards and forms of certification in this

\footnotetext{
*Corresponding author: m.wolinski@sgsp.edu.pl
} 
area are adequate for the new conditions. Below, narrower (but not less important) problem in the field of safety is discussed: if current regulations concerning explosion safety are adequate for the new conditions.

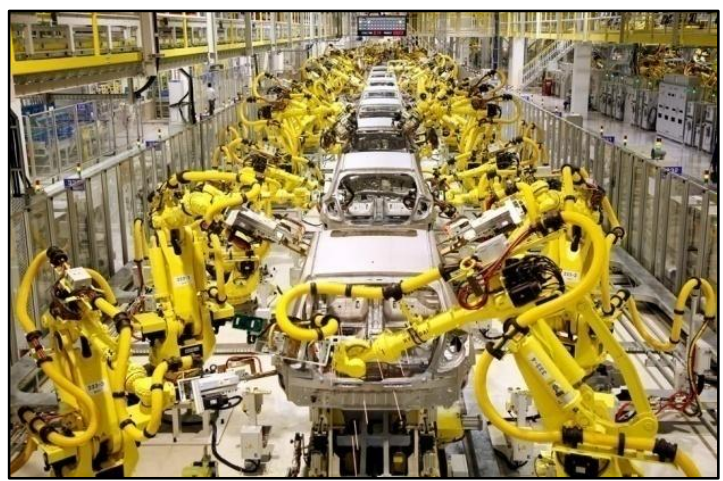

Fig. 1. Example of unmanned assembly line [4].

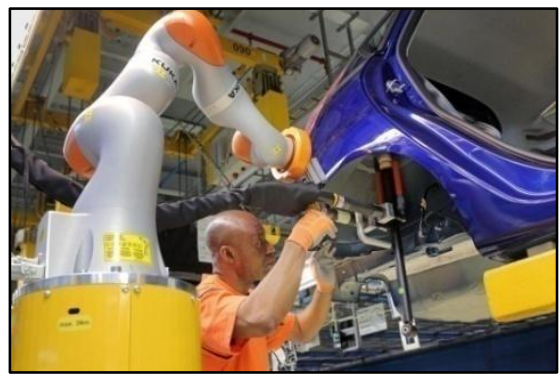

A)

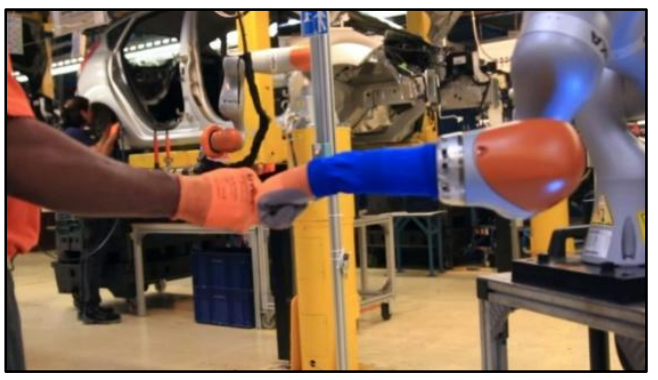

B)

Fig. 2. Assembly operations with support of KUKA's Light Weight Robot 4+ collaborative robot: A) [5], B) [6].

\section{Prevention of explosion and explosion protection}

The basic principles of explosion prevention and explosion protection are as follows:

a) prevention: avoid or reduce explosive atmospheres (what could be achieved by modifying either the concentration of flammable substance ta a value outside the explosion range or the concentration of oxygen to a value below the limiting oxygen concentration), avoid any possible effective ignition source,

b) protection: halting the explosion and/or limiting the range to a sufficient level by protection methods, e.g. isolation, venting, suppression and containment (in contrast to the two above preventive measures, here the occurence of an explosion is accepted) [7, 8]

Correct assessment of the explosion hazard in accordance with $[9,10]$ and the selection of appropriate (applicable in a given case) preventive and protective measures requires the determination of the properties of a mixture of a combustible substance with air, informing about the possibility of starting the explosion and behavior of substances during combustion. The following indicators inform about these properties:

- combustion properties: flash point [11], explosion limits (LEL, UEL) [12, 13], limiting oxygen concentration $[12,14]$, 
- ignition properties: minimum ignition energy (MIE) [15, 16], minimum ignition temperature of an explosive atmosphere $[17,18]$, minimum ignition temperature of a dust layer [18], spontaneous ignition behavior of dust accumulations [19],

- explosion behavior: maximum explosion pressure $\left(\mathrm{p}_{\max }\right)[14,20,21]$, maximum rate of pressure rise ((dp/dt) $\left.)_{\max }\right)$ [21- 23], maximum experimental safe gap (MESG) [24].

However, for better understanding and application of standard methods, testing requirements were combined recently into single documents: for explosive atmospheres with combustible dusts [25] and explosive atmospheres with gas and vapor [26].

\section{Regulations}

Avoiding or reduction of explosive atmosphere as preventive method in particular production process strongly depends on conditions of the process, and can be achieved by adequate design of the process, equipment used and its working conditions, as well as proper maintenance of equipment and production room, according to manual instructions or internal regulations (e.g. housekeeping in case of possible combustible dust release). For this purpose, crucial is the knowledge and experience of the process designer - supported by information on combustion properties of particular substance/substances used in the process, obtained with use of the discussed above standards.

Similarly - avoiding any possible effective ignition source. However, in this case efforts of process/equipment designer and user are targeted by special regulations [27] - ATEX Directive. In general, piece of equipment designed for work at hazardous area should not create an effective ignition source. Particular solutions, fulfilling this condition, could be suggested by the subsequent groups of standards:

- EN 13463: multipart document on non-electrical equipment for use in potentially explosive atmospheres,

- EN 60079: multipart document on electrical apparatus for explosive gas atmospheres and finally

- EN 80079, which is a quality management system for ATEX, connected with an EC type examination certificate or a conformity assessment according to the category of the devices.

The above "all - European" regulations could be supplemented by the national: e.g. $\$ 35$ of Polish ministry of interior regulation on fire protection [28] giving requirements on maximum admissible temperature of external surfaces of non electro energetic equipment exploited in areas with combustible gases and vapors or combustible dusts or fibers.

\section{Conclusions}

Existing regulations in the field of explosion safety at workplace are focused on workers (human) safety [8]. Demanded level of safety (acceptable level of occupational risk) at particular working place is achieved by practical application of the system of law regulations and related technical standards (as discussed above). Of course, this system is not closed - it develops together with challenges resulting from industrial development. But at present it looks sufficient: together with knowledge and common sense of equipment designers and user it can cover all predictable situations connected with work in areas with potentially explosive atmospheres.

Industry 4.0 includes cyber - physical systems, the Internet of things, cloud computing and cognitive computing. It creates a modular structured 'smart factory', in which cyber physical systems monitor physical processes, create a virtual copy of the physical world and make decentralized decisions. Over the Internet of Things, cyber - physical systems 
communicate and cooperate with each other and with humans in real time, and via cloud computing, both internal and cross - organizational services are offered and used by participants of the value chain [2]. For this reason Industry 4.0 is commonly referred to as the fourth industrial revolution [29].

However, all the features are (or will be) achieved with use of known, existing at present technical equipment. That equipment, if designed for work in areas with potentially explosive atmospheres have to fulfill requirements of [27, 8] (e.g. Fig. 3, below).

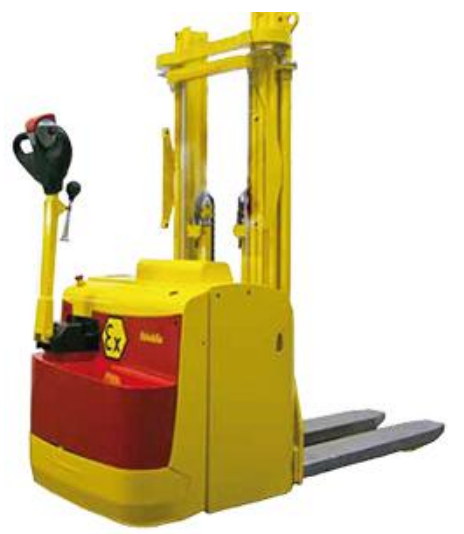

Fig. 3. Drawbar high lift truck EXI 16 for explosion hazard zones 1 and 21 (performance according to [30]) [31].

'Smart factory' of Industry 4.0 also have to be exlosion safe for its workers - even if they are autonomous robots. Of course, in case of explosion in unmanned plant there will be no problem of human losses (probably regulations of [8] will not be so important), but the problem of material losses remains (and the material losses in such a case could be more severe than in a 'typical' plant). So, the equipment for 'smart factory', where explosion hazard zones are expected or assessed, have to fulfill the same requirements as for 'typical' plant with explosion hazard zones. The system of regulations and standards in this area of safety exists and works properly, and hopefully there is no need for establishing new rules or new standards - new equipment (e.g. MOBOT ${ }^{\circledR}$ in Fig. 4, below) have to be designed, constructed, certificated, and finally - used according to [27].

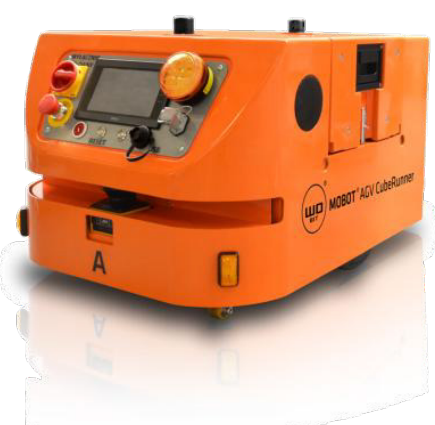

Fig. 4. Mobile robot MOBOT ${ }^{\circ}$ AGV CubeRunner (at present: performance for conditions without explosion hazard) [32]. 


\section{References}

1. Zukunftsprojekt Industrie 4.0 - BMBF. https://www.bmbf.de/de/zukunftsprojektindustrie-4-0-848.html accessed on Sept. 5th, 2018

2. Zukunftsprojekt Industrie 4.0 - BMBF. https://www.bmbf.de/de/zukunftsprojektindustrie-4-0-848.html accessed on Sept. 5th, 2018

3. M.I. Wolter et all (2015). doku.iab.de/forschungsbericht/2015/fb0815.pdf accessed on Sept. 6th, 2018

4. https://www.kulturpunkt.hr/content/buducnost-rada-i-radnicke-klase accessed on Aug. 24th, 2018

5. http://www.iocarrozziere.it/news/curiosita/item/560-cobot-una-linea-di-montagio-conrobot-collaborativi accessed on Aug. 24th, 2018

6. http://tiinside.com.br/tiinside/home/internet/22/06/2017/fabricas-inteligentes-devemadicionar-us-500-bilhoes-economia-global-nos-proximos-cinco-anos/ accessed on Aug. 24th, 2018

7. EN 1127-1:2011

8. Directive 1999/92/EC of the European Parliament and of the Council of 16 December 1999 on minimum requirements for improving the safety and health protection of workers potentially at risk from explosive atmospheres (15th individual Directive within the meaning of article 16(1) of Directive 89/391/EEC). Official Journal of the European Communities L 23/57, 28.01.2000

9. EN 60079-10-1:2016

10. EN 60079-10-2:2015

11. EN $15794: 2009$

12. EN $1839: 2018$

13. EN 14034-3:2006+A1:2011

14. EN 14034-4 :2004+A1 :2011

15. EN $13821: 2002$

16. ASTM E582-07(2013)e1

17. EN $14522: 2005$

18. EN 50281-2-1:1999

19. EN $15188: 2007$

20. EN 14034-1 :2004+A1 :2011

21. EN $15967: 2011$

22. EN 14034-2:2006+A1:2011

23. EN $14491: 2012$

24. EN 60079-20-1:2010

25. ISO/IEC 80079-20-2:2016

26. ISO/IEC 80079-20-1:2017

27. Directive 2014/34/EU of the European Parliament and of the Council of 26 February 2014 on the harmonisation of the laws of the Member States relating to equipment and protective systems intended for use in potentially explosive atmospheres (recast) (Text with EEA relevance). Official Journal of the European Union L 96/309, 29.3.2014 
28. Rozporządzenie Ministra Spraw Wewnętrznych i Administracji z dnia 7 czerwca 2010 r. w sprawie ochrony przeciwpożarowej budynków, innych obiektów budowlanych i terenów. Dz. U. 2010 nr 109 poz. 719 (in Polish)

29. B. Marr (2016). https://www.forbes.com/sites/bernardmarr/2016/04/05/why-everyonemust-get-ready-for-4th-industrial-revolution/\#52cefae23f90 accessed on Sept. 5th, 2018

30. IEC 60079-1:2014

31. https://www.stoecklin.com/en/floor-handling-equipment/explosion-protectionequipment/exi-16 accessed on Sept. 26, 2018

32. http://www.wobit.com.pl/produkt/12443/roboty-przemyslowe-mobot-agv/robotprzemyslowy-mobot-agv-cuberunner/ accessed on Sept. 26, 2018 